\section{International Scientific Journal Theoretical \& Applied Science}

p-ISSN: 2308-4944 (print) e-ISSN: 2409-0085 (online)

$\begin{array}{lll}\text { Year: } 2016 \quad \text { Issue: } 7 & \text { Volume: } 39\end{array}$

Published: $30.07 .2016 \quad$ http://T-Science.org
Rustamjon Sadriddinovich Samarov

$\mathrm{PhD}$, Professor,

Tashkent State Technical University Tashkent, Uzbekistan

Dustmurod Abdinazarovich Rakhmonov

Senior scientific researcher

The National University of Uzbekistan

Tashkent, Uzbekistan

muroddust-77@inbox.ru

SECTION 30. Philosophy.

\title{
SOCIAL WORK ACTIVITY IN PROVIDING THE LIFE OF THE SOCIETY (FUNCTIONAL-STRUCTURAL ANALYSIS)
}

\begin{abstract}
Social work (functions) has its phased development history. This article reflects the results of the analysis, the authors of the development of social work. Special attention is separated main functions and processes of institutionalization of social work with regional and mental characteristics.

Key words: philanthropy, the tradition, the Genesis of social work, social services, institutionalization of social work, social work activities, functions social service, methodology of social service, social work problems, a systematic approach to the theory of social work, philosophy of social work.

Language: English

Citation: Samarov RS, Rakhmonov DA (2016) SOCIAL WORK ACTIVITY IN PROVIDING THE LIFE OF THE SOCIETY (FUNCTIONAL-STRUCTURAL ANALYSIS). ISJ Theoretical \& Applied Science, 07 (39): 1416.
\end{abstract}

\section{Soi: http://s-o-i.org/1.1/TAS-07-39-3 Doi: crossef http://dx.doi.org/10.15863/TAS.2016.07.39.3}

Each profession has its own history and has come by solving the problems which occurred in the society. We should remember that it has effects of social-economic, political and cultural factors. As a profession is practical habits which are gained by a human's knowledge and experiences in order to carry out general, private preparations and certain movements. Every movement has its own content and it has been directed in order to solve any social problems. For instance social service specialists are busy with vexed issues, emotional problems, drinkers, people who are addicted to drugs, injured people, unemployed, homeless. There are various approaches [16] to forming this specialty.S.V.Teterskiy points out in his hand book "The introduction of social work" that social work was called as "filantropia" (to express love for human in Greek) in Greece while tradition of nation in Italy [7]. There are a lot of sources about it; this topic was drawled differently according to the place, aim and dates of the sources. For instance: some authors connect social work with appearing of religion while others think it's with the development of industry [8, 17, 18]. As the result of retrospective analyses and comparative analyses of the sources, social work has its own forming and development processes or steps.

- Primitive step (to take care of only close people);
- Cultural step (to help mentally and physically challenged);

- Institutional step (to help old people, babies under age and single mothers);

- Commercial step (social work as one type of labour in labour market).

In the primitive step of social work it's living with kind by doing morally good deed and kind works, in the cultural step one should help people who have physical and mental defects. Labour's subject and object have been created as well as its legal and economic bases during its institutional step. We can observe that social work is divided into branches according to people's requirements and demands in its commercial step.

Population's settlement, building, equipping, making national clothes, traditions of cooking and hospitality, daily lifestyle have a great influence on forming and developing social work in an autonomous way. For instance, in the period of Avesta also daily lifestyle was formed with taking into consideration of social demands and concerns. Furthermore it had its own terms and requirements. This issue is reflected clearly in the historical written document that was found in MugMountain, Sugd province [15].

According to this document men contracted with women not only taking all responsibilities. In such agreements they had to give guarantee on 
providing their rights. Today's world we need social work specialists more and study functional achievements of Western countries in order to develop of preparing specialists. S.Teterski [7] accepted the functional model of U. Bocharova's social teacher as a foundation and showed six functions. As the results of social works functionalstructural analyses, we'll show the following functions.

The function of holding diagnostics: Social work specialist studies a particular person or group's current state (defects, requirements, attitude to himself and others, waiting from others and specifies the level of microenvironment's effect. It means that he holds social diagnostics, evaluates needer's levels and state. For that, he should use such methods "defining the level of adoption", "Evaluating socializing", and "Specify assertive state".

Planning and directing function: it consists of putting order individual or group's problems (defects), marking therapeutic methods, specifying the ways of achieving maturity. The nature of the problem (defect) and its dynamics are taken into consideration especially time.

Function of making a prognosis: it defines social institutions which participate in helping social work objects, dynamic changes of social work objects after being helped. It also evaluates the results (it's possible to use V. Safronova's opinions).

Social therapeutic function warning prophylaxis: This function consists of giving sociallegal, socio-medical, psychological-pedagogical advices to people who need for preventing negative sides. These issues such as marriage, women, children the youth, couples, parents, the relationship between parents and children are possible to be chosen.

Function of protecting legally: using law collections in order to protect different classes of people. One should know labour law, family law, and citizenship right and get theory knowledge on legal institutions.

Social-pedagogical function directing people to social-profession according to their interest and needs, making equal the difference between personal and professional interests by using forming trainings, this function helps to take a shape of personal peculiarities.

Social-psychological function is to give psychological advices, help psycho correctively, the process of social adaption. For doing this function, it's necessary to use the bases of giving psychodiagnostic, psycho-correctional and psychological advices. It also consists of doing prophylaxis works in order to prevent diseases, first aid help, advising about eating habits, cleanliness measures, preparing the youth for future life, teaching healthy lifestyle to them.
Social-daily function is improving the living conditions of population (the disabled, the old, young family). For this function, a specialist needs to have professional knowledge on forming national, ethnic and daily lifestyle.

Communicative function is giving and exchanging information, attracting social institutions to social services. A specialist should have enough knowledge on the activities of social institutions.

The function of advertising propaganda is making advertisements in a good quality, propagandizing ideas which help master a proper possession in a society. For that, we should analyze the reasons of social problems.

Social cultural function is based on being guaranteed social customs and being followed these custom traditions, taking or giving social help forming the culture of giving social help also. It needs to held, organize holidays and ceremonies.

Organizational function is composed of attracting people to considerable works, helping various people or group socially and daily.

We can see easily that doing these functions is the work of a social specialist. Thus it is necessary for him to have professional knowledge not only daily knowledge. While professional knowledge gives the relation between social work specialists, particular person or group who needs social help, issue (defect) and helping practically the relation between social environments, social work specialist, particular person or group who need social help, micro environment, helping practically, daily life, issue (defect) having an aim in daily knowledge[12].

Despite of being difficult, cultural, professional, religious, national, age and sexual concerns should be taken into account in order to forming social work. Here we may show Professor R. Samarov's comparative analyses on West and East culture as an example. To his opinion, The West differs from the East with these peculiarities. The West is an anthropocentric zone. In the center of such society there is a human who makes nature and society, obey and become the king of the world. The East is a theocentric zone. In this zone these is a human for building the world and obeyed transcended freedom. Furthermore, realizing this will and following it by its tendencies is a human's tasks. According to the trends of society and human, the West is directed to material customs and the society tries to strive to general abundance which is understood as consumer's paradise. Spiritual customs are important in the East and the society is developed by spiritual and religious tendencies.[14] The aim of such developments is harmoniousity and abundance too. Furthermore, sexual peculiarities serve to draw the distance boundaries between a person who need help and a helper. Karen Xorni illustrated women's psychological peculiarities.[13] 


\begin{tabular}{|c|c|c|c|c|c|c|}
\hline Impact Factor: & $\begin{array}{l}\text { ISRA (India) } \\
\text { ISI (Dubai, UAF } \\
\text { GIF (Australia) } \\
\text { JIF }\end{array}$ & $\begin{array}{l}=1.344 \\
=0.829 \\
=0.564 \\
=1.500\end{array}$ & $\begin{array}{l}\text { SIS (USA) } \\
\text { PИНЦ (Russia } \\
\text { ESJI (KZ) } \\
\text { SJIF (Morocco }\end{array}$ & $\begin{array}{l}=\mathbf{0 . 9 1 2} \\
=\mathbf{0 . 2 3 4} \\
=\mathbf{1 . 0 4 2} \\
=\mathbf{2 . 0 3 1}\end{array}$ & $\begin{array}{l}\text { ICV (Poland) } \\
\text { PIF (India) } \\
\text { IBI (India) }\end{array}$ & $\begin{array}{l}=6.630 \\
=1.940 \\
=4.260\end{array}$ \\
\hline
\end{tabular}

They are characterized in this way in social life emotionality, effectively, listening to the heart:

- having more instinct in their nature;

- thinking about others intuitively;

- having open nature.

That's why it's essential to teach with professional knowledge which has age, sexual, regional, cultural and religious peculiarities while preparing for social work specialists.

Social work is a mean of providing of existing social politics, also means of being planned, being formed, and making propaganda.

Social work serous as defending human and society's need, planning and ruling the activities of social institutions defining the states in serial processes.

For instance Hobfoll S. E. and Lilly R.S. [11] divided into these groups of objects material objects (income, building, transport, clothes), non-material ones (wish, aim), external (social help, family, friends, job, social position), internal (self-respect, professional skill, self-control, belief, psychological and physical state). We can observe that these authors define objects only personally in a micro level and don't pay attention to their macro level. The macro level is composed of family, professional, national, religious levels and expresses the society's economic, social and cultural branches and their ruling level is connected with political branch.

Social work activity is serving in losing in born defects, making lone less, disabled people return to the life again. In every country it's getting developed. It's very essential to let social work specialist's work with communities, kindergartens, families, human. For this first of all making a theory model of these workers is important. We should work and develop the courses of social work philosophy, social work pedagogy, and social work sociology.

\section{References:}

1. Nefedova NK (1988) Problemy nacional'noj psihologii. - Moscow, 1988.

2. Ogurcov AP (1994) Trudnosti analiza mentalnosti // Zh. Voprosy filosofii. 1994, № 1.

3. Plotinskij JM (1992) Matematicheskoe modelirovanie dinamiki social'nyh processov. Moscow: MGU, 1992.

4. (1991) Psihologicheskoe obespechenie professional'noj dejatel'nosti / Pod red. G S. Nikiforova. - SPb.:Izd-vo SPbGU, 1991.

5. Sadriddinov S (2011) Shahsga hos psihologik nazarijalar va ularning қijosij taxlili // Y̌zbekistonning taraққijot jy̆li va izhtimoijfalsafij tafakkur jangilanishi. Josh olimlar ilmij konferencijasi materiallari. II - қіsm. Toshkent: Universitet, 2011.

6. Samarov R, Solieva F (1998) Rol' tradicii gumanizma $\mathrm{V}$ ukreplenii duhovnyh osnov obshhestva // Zh. Jekonomika i statistika. № 56, 1998.

7. Teterskij SV (2003) Vvedenie v social'nuju rabotu. - Moscow, 2003.

8. (2001) Teorija social'noj raboty / Pod. Redakcii E.I.Holstovoj. - Moscow, 2001.

9. Firsov MV, Studenova EG (2001) Teorija social'noj raboty. - Moscow: VLADOS, 2001.

10. Shadrikov VD (1980) Psihologicheskij analiz dejatel'nosti kak sistemy // Psihologicheskij zhurnal. 1980. T.1., № 3.

11. Hobfoll SE, Lilly RS (1993) Resource conservation as a strategy for community psychology //Journal of Community Psychology. 1993. № 21.

12. Samarow RS (2014) The scientific and theoretical aspects of the theory and practice of social work $/ / 9^{\text {th }}$ International scientific conference "European Applied Sciences: modern approaches in scientific researches" 31th March 2014 Stuttgart, Germany. pp. 8990.

13. Khorni K (1993) Zhenskaya psikhologiya / Izbrannye glavy iz knigi. (Pod redaktsiey A.I.Belkina, M.M.Reshetnikovai, S.I. Sedena). - SPb.: Sankt-Peterburgskiy institut psikho analiza., 1993.

14. Samarov RS (2010) Khavfsizlikning metodologik asoslari. - Toshkent: Akademiya, 2010. - pp. 129.

15. (1999) «Avesto»: ael va oila masalasi // Zh. Yzbekiston iktisodiy akhborotnomasi. 1999,8son.-pp. 58-60.

16. (2002) Istoriya sotsial'noy raboty. - Moscow, 2002.

17. Kuz'min KV, Sutyrin BA (2002) Istoriya sotsial'noy raboty za rubezhom i v Rossii (s drevnosti do nachala KhKh veka). - Moscow: Akademicheskiy proekt, 2002.

18. (1999) Osnovy sotsial'noy raboty. Uchebnik./ Otv. red. P.D.Pavlenok.- Moscow: INFRA-M, 1999. 